\title{
Effect Of Bacteria Growth on the Biodegradability of Visco 2000- Sae20 (V20) and Super-V Sae 20 (S20) Engine Oil.
}

\author{
E. M. Omoghie ${ }^{1,3}$ U. Udochukwu ${ }^{2}$ A. O. Oshionebo ${ }^{3}$ \\ ${ }^{1}$ Department Of Microbiology, Faculty Of Life Science University Of Port Harcourt, River State, Nigeria \\ ${ }^{2}$ Department of Bioscience, College of Natural and Applied Sciences, Salem University-lokoja, Kogi State, \\ Nigeria \\ ${ }^{3}$ Department Of Microbiology, Faculty Of Life Science University Of Benin, Edo State, Nigeria
}

\begin{abstract}
The biodegradability of petrol based engine oils produced by African Petroleum (AP) filling station was investigated for a period of twenty-eight (28) days. Two different samples of AP engine oils, Visco 2000SAE20 (V20) and Super-V SAE 20 (S20)) were investigated. Soil from a mechanic workshop in Alakahia village near the University of Port Harcourt, Rivers State, Nigeria served as seed for the biodegradation. The study was carried out at room temperature $\left(27-29^{\circ} \mathrm{C}\right)$. The $\mathrm{pH}$ of the test systems ranged from 6.5 to 7.4 . The counts on the first day were $2.62 \times 10^{5}$ and $2.47 \times 10^{5}$ for V2O and S20 respectively. Whereas the corresponding counts in $28^{\text {th }}$ day were $2.70 \times 10^{6}$ and $1.86 \times 10^{6}$ in colony forming unit per milliliters (cfu/ml). The hydrocarbon utilizing bacteria (HUB) isolated include Bacillus, Citrobacter, Micrococcus, Proteus, Pseudomonas, and Vibrio. The physicochemical analysis showed that nitrate, phosphate, sulphate, biochemical oxygen demand, (BOD), oil and grease content and total organic carbon (TOC) decreased with time. The rate of biodegradation between the two engine oils was in accordance with the normal growth rate for a close system.
\end{abstract}

Key Words: Biodegradability, Hydrocarbon Utilizing Bacteria (HUB), Petrol Base Engine Oils, Biochemical Oxygen Demand (BOD) and Total Organic Carbon (TOC)

\section{Introduction}

The chemical analysis of engine oils revealed that they contain a high content of polycyclic aromatic hydrocarbon (naphthalene, anthracene, phenols, and other derivatives) and a small fraction of aliphatic hydrocarbons $\left(\mathrm{nC}_{15}-\mathrm{nC}_{40}\right)$. These chemical constituent present in the engine oils can cause environmental pollution when spill is experienced. The pollutants destabilize the environment (soil, atmosphere and water body) as well as the biotic component of the environment as a result of their toxic effects which thereafter adversely affect the human inhabitants. In other to effectively stabilize the environment resulting from oil spills, there is need for biodegradability study. Biodegradability is the capacity of a material to decompose over time as a result of biological activities, especially to be broken down by microorganisms. The study is aimed at identifying most appropriate organism or group of organisms which can be used for effective bioremediation when there is spillage. As the usage of petroleum products increases, soil contamination with engine oil is becoming one of the major environmental problems [9]. Degradability of engine oils is crucial since most of the mechanical methods to reduce hydrocarbon pollution are expensive, time consuming and dependent mainly on of excavating of these soil, and treating in separate area in better treatment facilities. These treatments include for example, incineration and or buried in secured landfills [12]. Though these treatments are effective but after burning, this soil looses their nutritional value and structure. These methods do not remove the contamination but only relocate the problem [8]. Microbial degradability is accomplished with the help of diverse group of microorganisms, particularly indigenous bacteria present in soil which are ubiquitous in nature. These organisms can degrade a wide range of target constituents present in oil sludge [10]. The biodegradability of oil pollutants has been intensively studied in controlled conditions [3] and in open field experiments [4].

\section{Materials And Methods}

The soil samples were collected at Alakahia village near the University of Port Harcourt, Rivers State, Nigeria. Soil samples for biological analysis were obtained from different points (about ten meters apart) and pooled together to form composite samples. Four types of unused engine oils produced by African Petroleum (AP) were obtained from AP filling station located beside University of Port Harcourt Road, Choba, Rivers State, Nigeria. Visco 2000-SAE20Wand Super V-SAE20W were aseptically taken to the laboratory for analysis. The soil sample was weighed and $10 \mathrm{~g}$ was dissolved in $90 \mathrm{ml}$ of distilled water to obtain a ten-fold (10 fold) dilution of the soil sample. Toxicity test was conducted to obtain non-toxic concentration. The test was conducted by measuring equal volumes $(10 \mathrm{ml})$ from the 10 -fold dilution of the soil sample into four conical 
flasks. Different volumes of $0.1 \mathrm{ml}, 1.0 \mathrm{ml}$ and 10.0 of the engine oils were transfer into the flasks. One of the flasks served as control which was free from engine oil. The volumes were made up to $100 \mathrm{ml}$ with sterile distilled water. This resulted to concentrations of $1 \mathrm{mg} / 1,0.1 \mathrm{mg} / \mathrm{l}$ and $0.01 \mathrm{mg} / \mathrm{l}$ of the engine oils. The cultures were incubated for 24 hours at $37^{\circ} \mathrm{C}$. The non toxic concentrations of the two engine oil were determined by plating out in a nutrient media by spread plate method and were incubated for 48 hours at $37^{\circ} \mathrm{C}$. The sample inoculated with engine oil that produced similar counts with control after two days of incubation was taken as the non toxic concentration of the oil to the organisms [12].

The biodegradation conditions of the experimental set up were monitored by withdrawing the samples before initiation of the experiment at the first day and subsequently at day 7, 14, 21 and 28 for microbiological and physical chemical analysis. Total heterotrophic bacterial (THB) counts of the withdrawn samples were performed. Serial dilution using normal saline $(0.85 \%)$ as diluents was done and spread plate technique was adoptedusing Nutrient agar and incubated for $48 \mathrm{~h}$ at $37^{\circ} \mathrm{C}$. Vapour phase transfer method was adopted in estimating the population of hydrocarbon utilizing bacteria. Mineral salt agar with a sterile filter paper (whatmann No. 1) saturated with the oil which supplied the hydrocarbon by vapour phase transfer to the inocula were incubated (room temperature for 5 days). Physicochemical analyses were carried out such as $\mathrm{pH}$, total organic carbon, biochemical oxygen demand (BOD), oil and grease analysis, alkalinity analysis, sulphate content, nitrate content and phosphate content to determine the rate of degradability of the oils.

Table: Non-toxic concentration determination $(\mathrm{cfu} / \mathrm{ml})$

\begin{tabular}{|c|c|c|c|c|}
\hline $\mathbf{S} / \mathbf{N}$ & Oil Sample & & $\mathrm{mg} / \mathrm{l})$ & \\
\hline 1.0 & & 0.1 & 0.01 & \\
\hline 1. & V20 & $6.42 \times 10^{3}$ & $3.32 \times 10^{4}$ & $2.82 \times 10^{5}$ \\
\hline 2. & $\mathrm{~S} 20$ & $8.34 \times 10^{3}$ & $7.82 \times 10^{3}$ & $1.74 \times 10^{5}$ \\
\hline 3. & Control (wi & ut oil) 2.9 & & \\
\hline
\end{tabular}

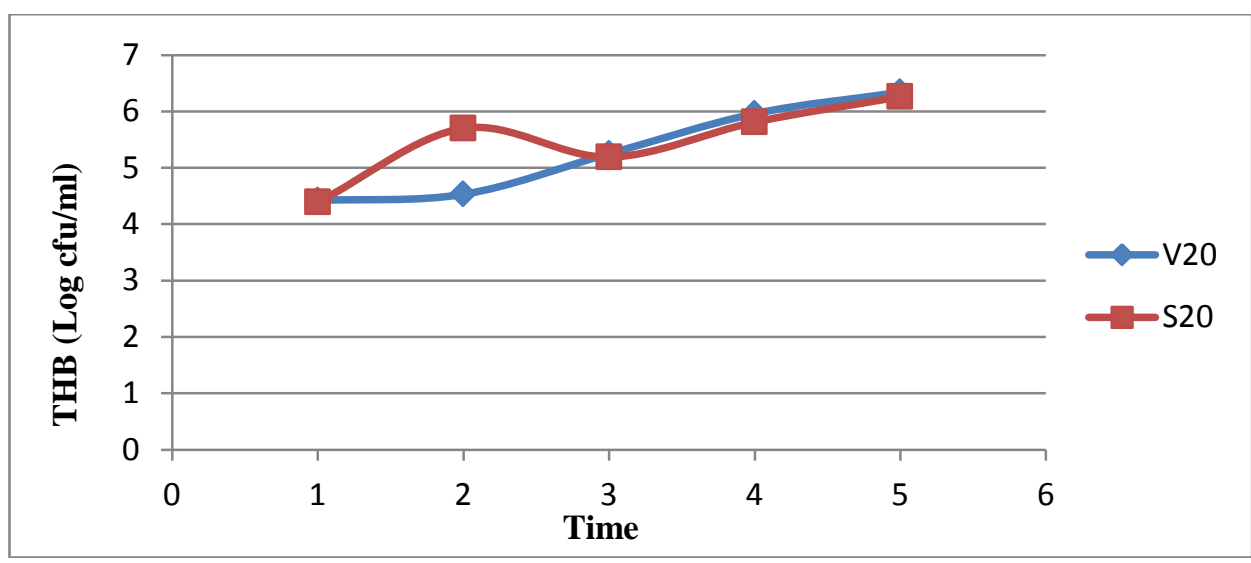

Fig 1. Change in total heterotrophic bacterial count $(\log \mathrm{cfu} / \mathrm{ml})$ of the test system

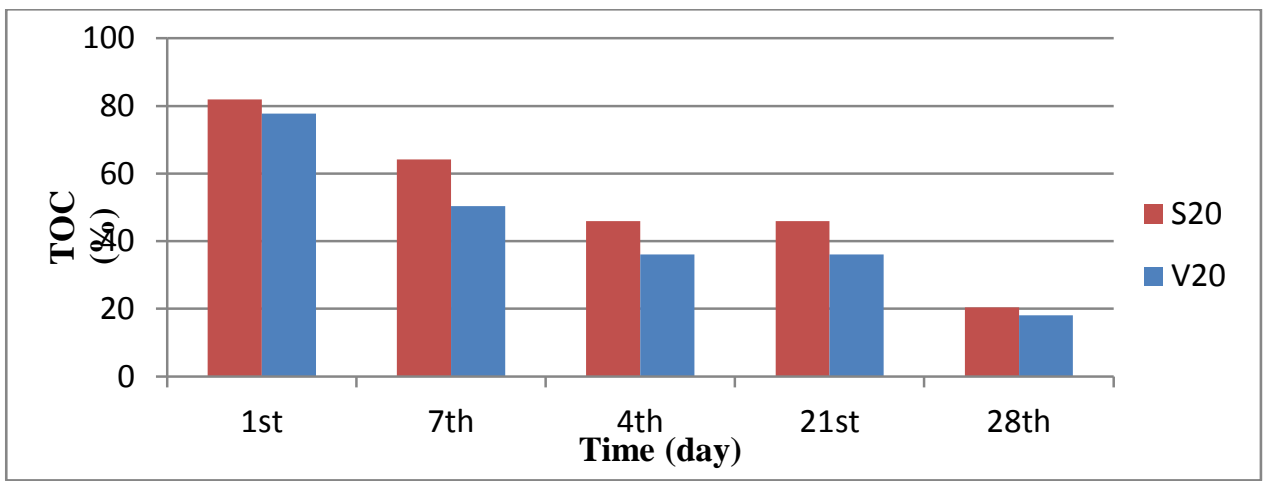

Fig 3. Change in percentage (\%) of total organic carbon of the test system 


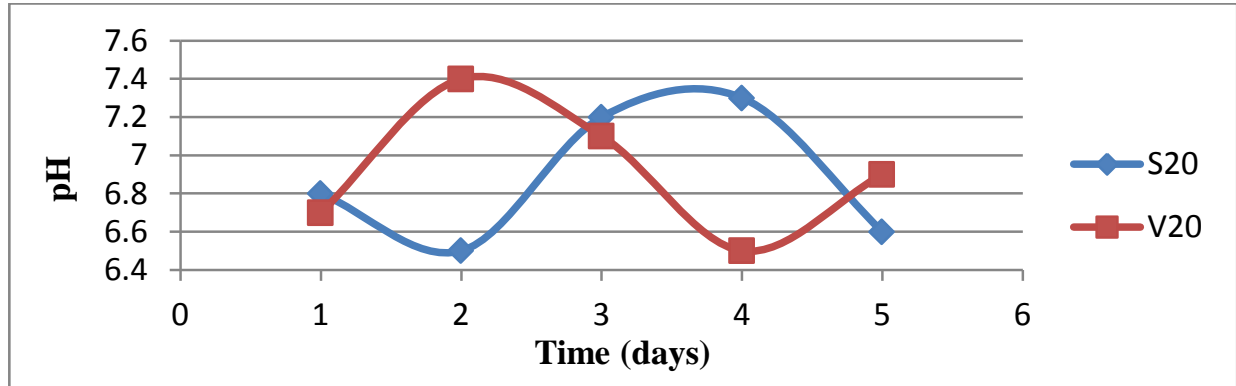

Fig. 4. Change in $\mathrm{pH}$ of the medium for the test systems.

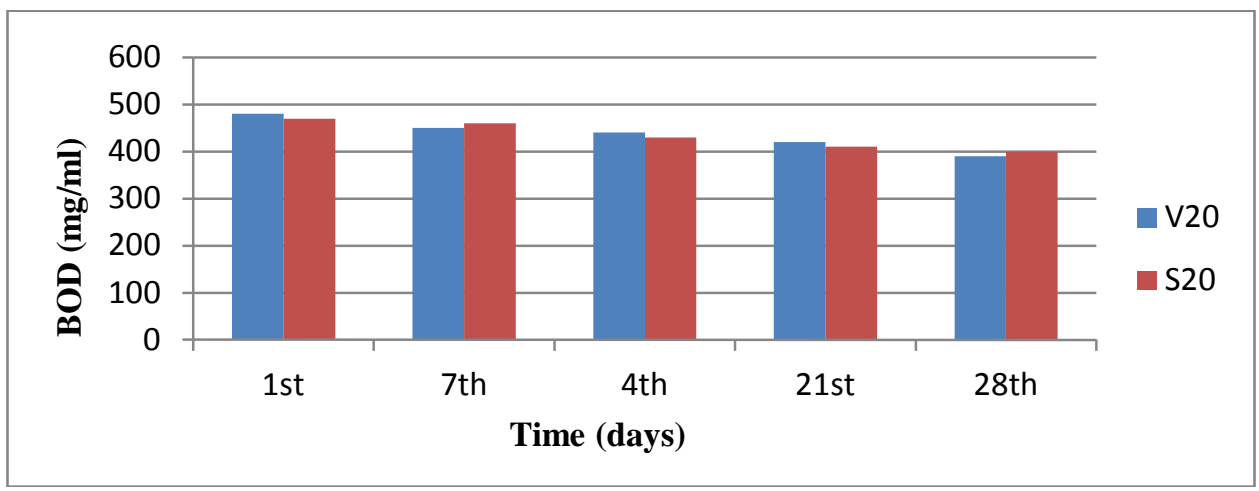

Fig. 5. Change in BOD of the test systems.

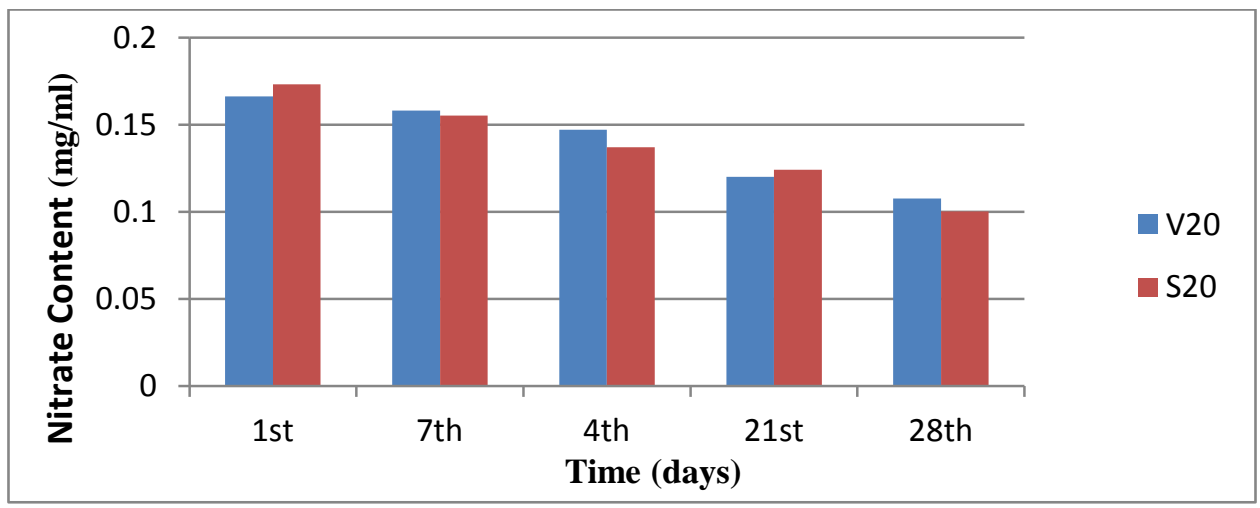

Fig. 6. Change in concentration of nitrate content for the test systems.

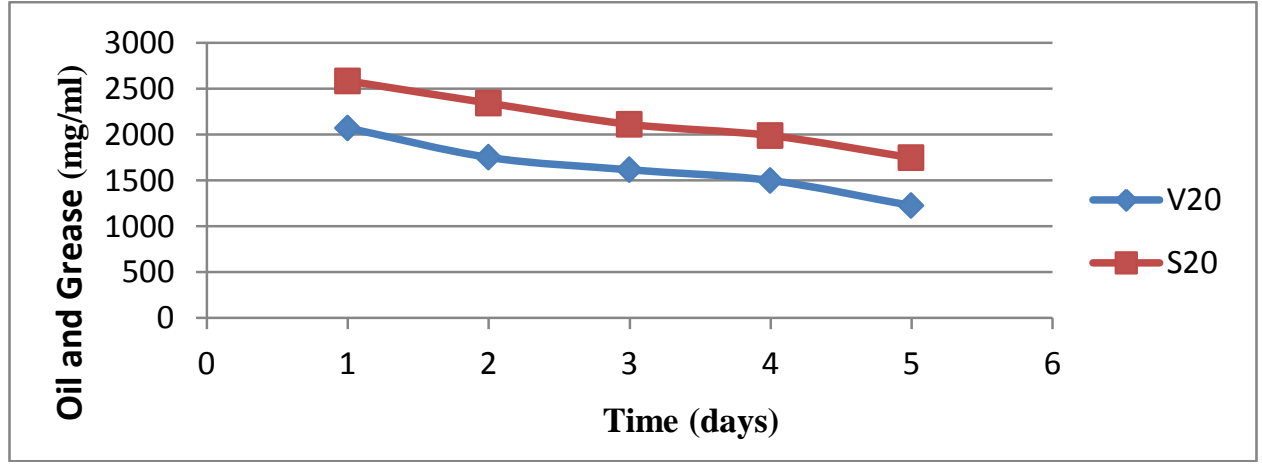

Fig. 7. Change in oil and grease of the test systems. 


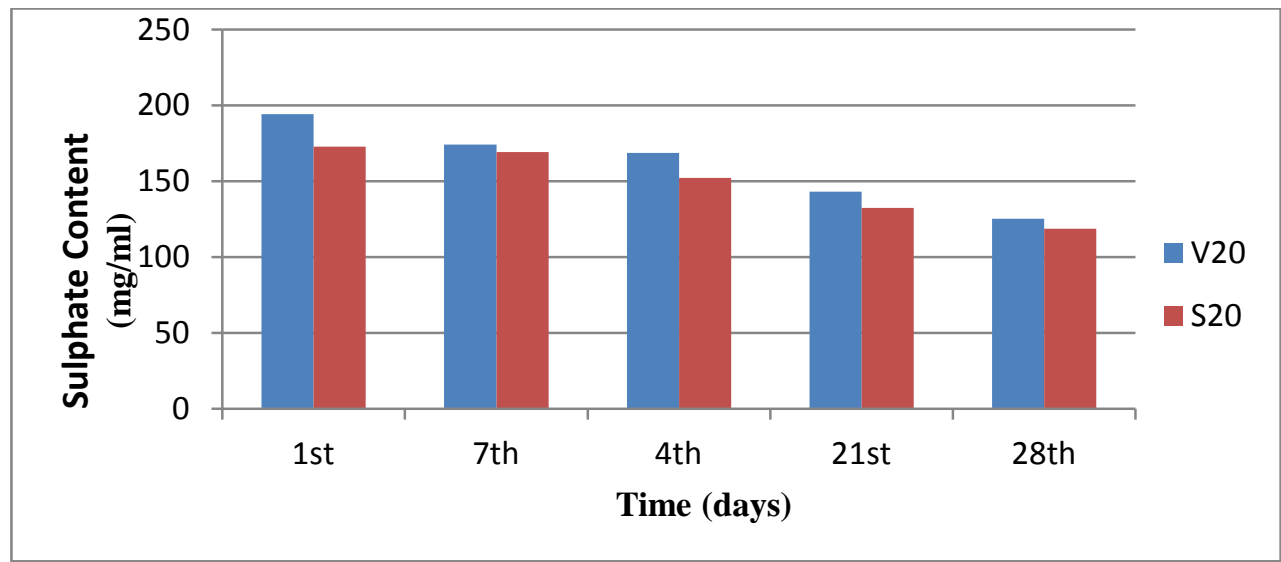

Fig. 8. Change in the concentration of sulphate content of the test systems.

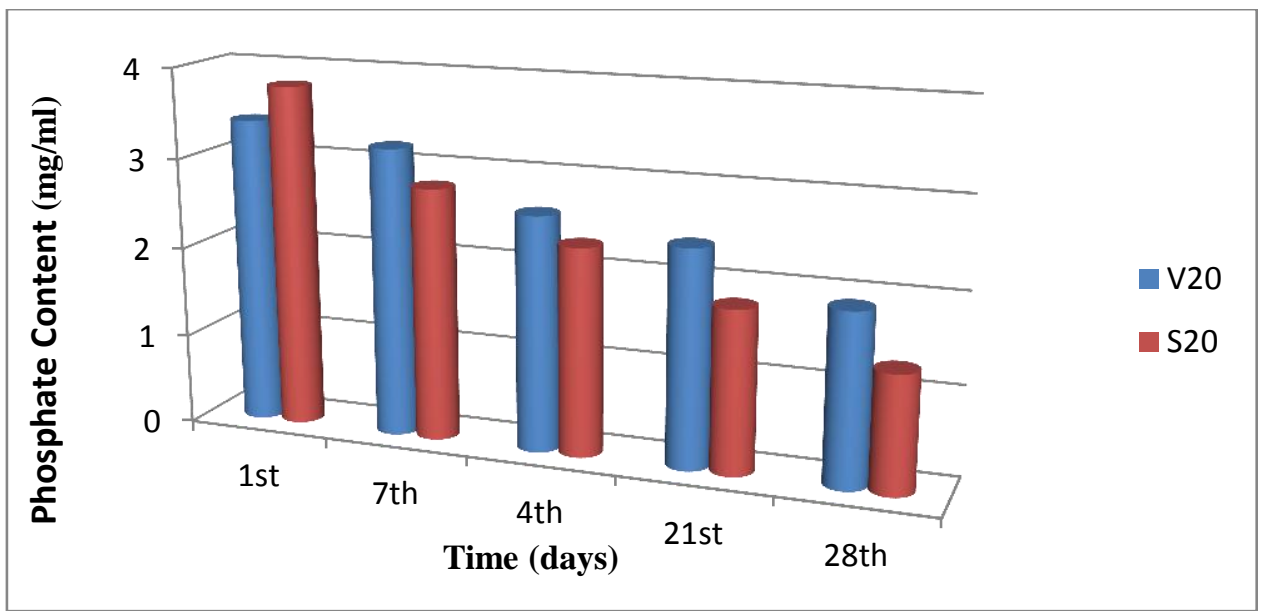

Fig. 9. Change in the concentration of phosphate content of the test systems.

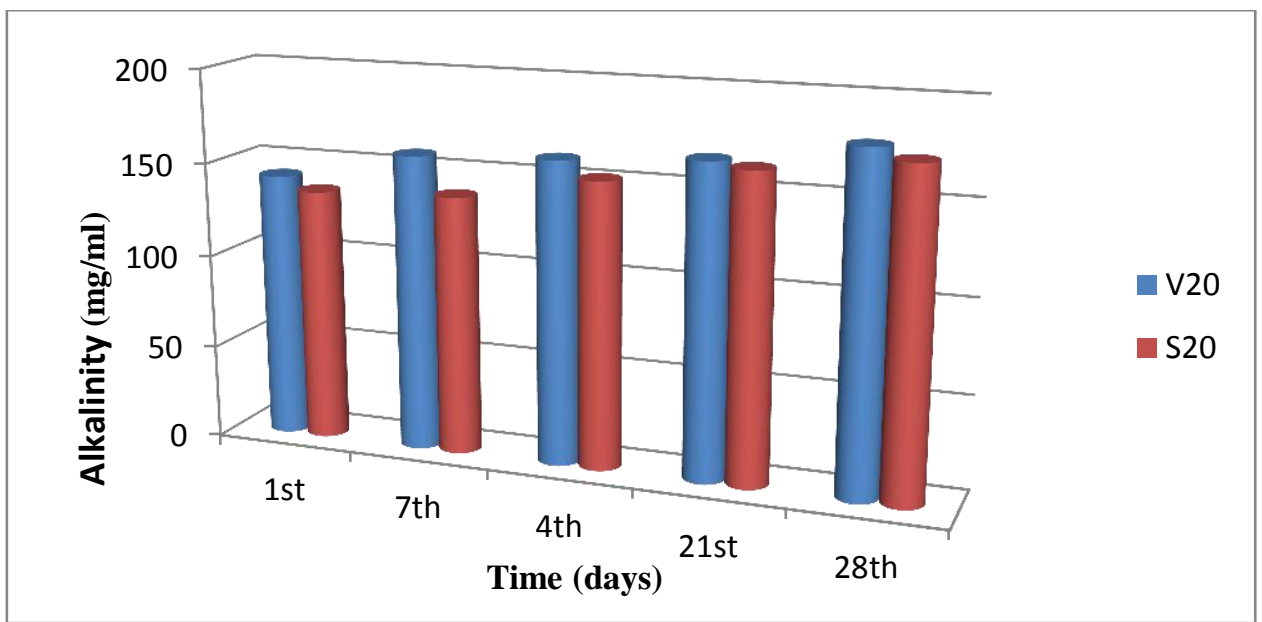

Fig. 10. Change in alkalinity of the test systems.

\section{Results}

The toxicity test to determine the non-toxic concentration by serial dilution of engine oils were evaluated (cfu/ml) and the results are shown in the table above. The dilution on which the values were equivalent or almost equivalent to the control were considered as the non toxic concentration as in $0.01 \mathrm{mg} / \mathrm{ml} \mathrm{in}$ the table. Most of the bacteria isolated were cream coloured, few were yellow and others white. The morphology and biochemical analyses showed that the generic compositions of the isolates include Bacillus, Citrobacter, Micrococcus, Proteus, Pseudomonas, and Vibrio. The results of the physicochemical analyses for the engine oils for the period of 28 days are showed in the figures 2-10 above. The $\mathrm{pH}$ obtained in comparison 
with time zero and twenty-eight day considerably fluctuate near neutrality. The decrease during the 28 days biodegradation process observed for all the parameters indicates that there were active utilization of oxygen and other nutrients available in the test system.

The $\mathrm{pH}$ profile obtained generally fell between the optimum range of 6.5 and 7.4 which favors most of the heterotrophic microorganisms though the values did not follow a consistent trend as for the other parameters, it showed that microorganisms utilizing bacteria as nutrient produce metabolic products. These metabolic products must have contributed to the fluctuation of the $\mathrm{pH}$ readings near neutrality. It was also observed that the nutrients (sulphate, phosphate and nitrate) decreased considerably with time as the research elapses. The decrease is understandable as they are used in the metabolism of microorganism in building biomass. There is correspondence in the utilization of phosphate, sulphate and nitrate indicating their relative importance in cell metabolism as stated by Odum's combine law. The biochemical oxygen demand (BOD) of the media were decreasing as the study progress indicating that the oxygen content in the medium is been utilized by the aerobic microorganisms.

\section{Conclusion}

Engine oils have been found to be susceptible to microbial attack and hence biodegradation or even biodeterioration of unused engine oils can occur. Microorganisms are known to attack engine oils as sole source of carbon and energy [15] Most of the bacterial isolates were Gram negative which is in accordance with the report of [14] who showed the predominance of Gram negative bacteria in oil samples. The bacteria which include; Bacillus, Citrobacter, Micrococcus, Proteus, Pseudomonas, and Vibrio has been isolated and identified from various petroleum products [7, 11, 14]. Researchers have reported that Pseudomonas aeruginosa [7] as the predominant species in petroleum product which is in accordance with this research. This is expected because the genus is commonly found everywhere especially in oil polluted area [6]. The total heterotrophic bacteria differ from those of the hydrocarbon utilizing bacteria when compared. This is due to the ability of the heterotrophic bacteria to withstand stress with time and have resided in the water phase where little nutrient is available. Though there were appropriate bacterial populations in the samples, hydrocarbon degradation is near impossible if necessary nutrients were not available. It is well established that the availability of nitrogen and phosphorus limits the microbial degradation of hydrocarbons [12]. From the graphs, it can be observed that the phases of growth followed a normal batch growth curve pattern of log, exponential, stationary and death phases.

The results of the research have shown that the degradability of the engine oils were positive and in accordance with the previous researches. Time series degradation processes by indigenous microorganisms from the soil have shown to be relatively efficient in the breaking down of petroleum products as evidently indicated by the physicochemical analysis.

\section{References}

[1]. Amanchukwu S.C., Obafemi A. and Okpokwasili, G.C. (1989). Hydrocarbon Degradation and Utilization by Palm Wine Yeast Isolates.FEMS Microbiol. Letters 57: 151-154.

[2]. Anthony and Okoh (2006). Biodegradation Alternative in the Cleanup of Petroleum Hydrocarbon Pollutants.Biotechnol. Mol. Biol. 1: $38-50$.

[3]. Chaillan F., Chaineau C. H. Point V., Saliot A., and Oudot J. (2006). Factors Inhibiting Bioremediation of Soil Contaminated with Weathered Oils and Drill Cuttings. Env. Pol 144: 255-265.

[4]. Chaineau C. H., Rougeux G., Yepremian C. and Oudot J. (2005). Effects of Nutrient Concentration on the Biodegradation of Crude Oil and Associated Microbial Populations in the Soil.Soil Biol. And Biochem.37: 1490-1497).

[5]. Cheesbrough M. (2006). District Laboratory Practice in Tropical Countries. McGraw Hill Publishers, New York.pp 143-156.

[6]. Fought J. M. and Westlake D. W. S. (1988). Degradation of Polycyclic Aromatic Hydrocarbon and Aromatic HeterocyclesByPseudomonas species. Can. J. Microbiol.34: 1135-1141.

[7]. Hill E.C. (1978). Microbial Degradation of Marine Lubricants, Its Detection and Control.Trans. Inst. Marine Engrs. 90: 197-216.

[8]. Lageman R., Clarke R. and Pool W. (2005). Electro-reclamation, A Versatile Soil Remediation Solution.Eng. Geol. 77: 191-201.

[9]. Madri T. and Linn J. (2007). Isolation And Characterization of Engine Oils Degrading Bacteria Indigenous Microorganisms In Kwazulu-Natal, South Africa. Afr. J. Biotechnol. 6: 23-27.

[10]. Mishra S., Jyot J., Kuhad R. C. and Lal B. (2001). Evaluation of Inoculums Addition to Stimulatein situ Bioremediation of Oil Sludge Contaminated Soil. Appl. Env. Microbiol. 67: 1675-1681.

[11]. Naylor, T. W., Brown L. A. and Powell K. A. (1982). Microbiological Investigation of Turbine Oil Spillage.Trib. Int. 15: 182-186.

[12]. Odokuma L. O. and Dickson A. A. (2003). Bioremediation of Oil Polluted Mangrove Environment. JESEM. 7: 23-30.

[13]. Odokuma L. O. and Okpokwasili G. C. (1993). Role of Composition in the Degradability of Oil Spill Dispersants.Waste Manage. 12: $39-43$.

[14]. Okpokwasili G. C. and Okorie B. B. (1988). Biodeterioration Potentials of Microorganisms Isolated from Car Engine Lubricating Oil. Trib. Int. 21: 215-220

[15]. Okpokwasili G. C. and Okorie B. B. (1991). Influence of Physicochemical Stress of Biodegradability of Car Engine Lubricating Oil.Int. Bioter. 27: 255-264. 